\title{
Unlocking the Institutionalization Process: Insights for an Institutionalizing Approach
}

\author{
Clóvis L. Machado-da-Silva* \\ E-mail address: clms@terra.com.br \\ Escola de Administração de Empresas de São Paulo - Fundação Getúlio Vargas \\ São Paulo, SP, Brazil \\ Valéria Silva da Fonseca \\ E-mail address: vsdf@mais.sul.com.br \\ Pontifícia Universidade Católica do Paraná \\ Curitiba, PR, Brazil \\ João Marcelo Crubellate \\ E-mail address: jmcrubellate@terra.com.br \\ Centro Universitário Positivo \\ Curitiba, PR, Brazil
}

\begin{abstract}
The neoinstitutional theory has been characterized by some scholars in the field of organizational studies as a supposedly deterministic approach. We will demonstrate in this paper that this characterization cannot be impinged on the neoinstitutional perspective in a generalized way, but only to a dichotomic reading of it, that is typical of monoparadigmatic views of the process of institutionalization. With this demonstration, we defend the idea of the institutional theory as a multiparadigmatic theory. To this end, we present arguments for a recursive approach of the institutionalization process, highlighting that the notions of structure, agency and interpretation are more suitably dealt with when defended as fundamental elements of institutionalization as a recurrent, guaranteed process that is conditioned, not determined, by a certain degree of stabilization of social systems. We conclude the essay with methodological considerations on the consequences of the use of the proposal for a recurrent systemic-process approach of institutionalization for the development of research in the field of organizational studies.
\end{abstract}

Key words: institutional theory; institutionalization; social structure; agency; interpretive schemes.

Received 20 October 2004; received in revised form 20 December 2004.

Copyright (C) 2005 Brazilian Administration Review. All rights reserved, including rights for translation. Parts of this work may be quoted without prior knowledge on the condition that the source is identified.

*Corresponding author: Clóvis L. Machado-da-Silva

Av. Visconde de Guarapuava, 4487, Apt. 4, Edifício Paul Cézanne, Batel, CEP 80240-010, Curitiba, PR, Brazil. 


\section{INTRODUCTION}

Despite the customary references to the works of Philip Selznick that were published in the forties and fifties of the twentieth century, the origins of the institutional theory go back to the nineteenth century, as demonstrated by Scott (2001) through a clarifying synthesis of the emergence and development of this approach in social sciences, most notably in political science, economics and sociology. Nevertheless, the popularity of the institutional theory is a relatively recent phenomenon in academic circles, especially over the last few decades.

In the field of organizational studies specifically, it is noteworthy the growing adhesion of researchers to the institutional perspective, both in Brazil and abroad. This popularity is probably due to the fact that few theories have been so productive in organizational studies in recent years. This may in part be because the approach has been subjected to such intense criticism, and not always from scholars of other theoretical perspectives, but mainly adepts of the institutional theory itself, or, at least, those who explore its interface with other analysis sources of organizations (see, for instance, DIMAGGIO; POWELL, 1991; OLIVER, 1991; SELZNICK, 1996; TOLBERT; ZUCKER, 1996).

Such criticisms are generally made based on conceptual statements that supposedly result from the process of institutionalization and culminate in the suggestion of a subjacent determinist tendency towards a specific version of institutional theory, which was later designated as neoinstitutionalism. Even at the moment in which the neoinstitutional theory is gaining ground in the field of organizational studies, this critical guidance appears in the mentioned mould.

In Brazil, this supposed determinist tendency has recently been interpreted by Carvalho, Goulart and Vieira (2004) as moral conservatism. However, by treating the concepts of determinism and conservatism as equivalent, these authors remove the debate from the scientific field to the moral sphere of judgment of values. By proceeding in this way, they ignore the set of values that sustain scientific practice, which constitute the criterion by which a theory should be evaluated as rationally acceptable, for positioning in the contradictory and intricate world of moral values. Praxiological values of the nature of scientific endeavour, with their many notions and possibilities, are important in the context of assessment of scientific activity. It is necessary to separate them analytically from moral values in order to reach intersubjective coherence on the foundations of scientific judgments that lead to the acceptance or rejection of theoretic formulations.

The analytic separation of these types of values is related to the notion of legitimacy of scientific practice, circumscribing the evaluation of theories to the ontological and epistemological bases that provide them with support. Thus, the simplifying reduction to the concept of neutrality is avoided, a clear impossibility in social sciences, and removed to the debate of the understanding of acceptable criteria, from a necessarily rational viewpoint, all the while limited and in process of permanent redefinition, for assessment, development and choice of theories.

In this light, Lacey (1998) discuss on the analytical possibilities of the concept of impartiality, in contraposition to the concepts of neutrality and autonomy, for the verification of theories. Impartiality, as a scientific reference value in his view, needs to be an ideal to be sought out, as neutrality and autonomy constitute impossibilities because of the involvement of the researcher and the complex and contradictory diversity of social values. As a scientific ideal, impartiality refers specifically to the epistemic reasons for accepting or rejecting theories, meaning that "the relationships that a theory maintains with any perspective of value are irrelevant to its legitimate acceptance" (LACEY, 1998, p. 14). The concept of impartiality is related to the necessary exercise of analytical distancing or bracketing on the part of the researcher, who cannot be neutral or autonomous, but seeks to maintain coherence with the presupposed epistemological and ontological references to the notions of science and society that are subjacent to the theoretic perspective that he/she adopts for his/her analysis of the social world. 
It is fitting to add that the equivalence attributed to the concepts of determinism and moral conservatism by Carvalho, Goulart and Vieira (2004), seems to rest on the maniqueist view of the world, which can be seen from the prescriptive posture that permeates their paper. As a result, the institutional perspective is reduced by them to a simple dichotomic approach, in which persistence and change are opposed: persistence is, by definition, a negative attribute, as it is necessarily conservative; change is, also by definition, a positive attribute because it is necessarily reformative. Note that if effectively taking into consideration the equivalence of the concepts of determinism and persistence to the epithet of conservatism, this will withdraw the possibility of treating them as descriptive concepts that are scientifically useful in the field of institutional theory.

We state that the dualism between persistence and change leads to the distortion of notions and concepts for the better understanding and for the very development of the institutional theory. These notions and concepts, seen from a systemic-process perspective of duality rather than dualism between persistence and change, of procedural recurrence between homogeneity and heterogeneity, of recursiveness between structure and agency, are essential for the full understanding of the institutional theory in the light of the ontology and epistemology that sustain the definition of its presuppositions and for its adequate utilization in the area of organizational studies.

From the ontological viewpoint, the stance that we have adopted is neither objectivist nor subjectivist. It is decidedly intersubjective. We understand that the concept of intersubjectivity is more suitable as a presupposition of a recursive approach of the institutionalization process. The notion of intersubjectivity allows for the establishment of bridges with the concepts of the subjectivity and the objectivity, as it refers to the sharing of meanings attributed by individual actors in each specific situation in social space and time, guaranteeing relative, temporal and especially delimited objectivity. The epistemological, theoretic and methodological developments of this assumption are explored later in this paper.

With this in mind, the aim of this paper is to introduce, for the reflection of those who are dedicated to understand and perfecting their knowledge of the institutional theory, elements for the adoption of a recursive approach to the institutionalization process, in contraposition to the employment of any dichotomic viewpoint that imposes limits to the progression of the institutional perspective. We intend to demonstrate that structure, agency and interpretation are more suitably dealt with when defined as fundamental elements of institutionalization as a recurrent, guaranteed process that is conditioned, not determined, by a certain degree of stabilization of social systems. As such, it is an institutionalizing approach for the institutionalization process.

In accordance with this line of reasoning, it is the role of the social actors, through their capacity for agency, to participate in the process of social construction of reality, dealing with structural conditioning that not only constrain but also enable for social action as they are created by the social actors themselves through intersubjective sharing of meanings. In coherence with this position, the guidance that we have adopted is that which is concerned with the notion of the intellectual as specifically oriented, in opposition to the moral-authoritarian posture of the intellectual that holds the universal focus, as defined by Foucault (1979). For an interesting analysis of this distinction proposed by Foucault, see Adorno (2004).

With the aim of unfolding and deepening the preceding arguments, this paper is organized into the following sections: the institutional theory and its critics; the institutional theory as a multiparadigmatic theory; structure, agency and the precedence of interpretation: institutionalization as a recursive process; and, lastly, the conclusion. 


\section{INSTITUTIONAL THEORY AND ITS CRITICS}

Zucker (1991) begins her discussion concerning the differentiation between institutionalization and cultural persistence with the indication of the permanence of social characteristics as a commonly accepted definition for the concept of institution. To the author, the traditional explanations for the persistence of cultural characteristics link it to the institutional phenomenon. As for the systemic view, institutional or cultural patterns persist because they fill functional needs. In the normative view, they persist because they are set, or are internalized, while they are shared norms of action. According to her, in both views, "[the] actor plays no independent role in maintaining these institutions; [cultural patterns] serve to constrain his behavior. The social structure (macrolevel) determines the behavior of individuals and small groups (microlevel) and exists independently of them" (ZUCKER, 1991, p. 84).

In these terms, Zucker $(1987,1991)$ includes the development of institutional theory realized up to that point in the paradigmatic realm of functionalist theory and proposes an interpretive way (ethnometodological and phenomenological) to it. She thereby distinguishes cultural persistence as a result and no longer as a characteristic of the institutionalization process, suggesting that the degree of institutionalization grows up to the extent of increasing transmission, maintenance and resistance to change of shared cultural patterns.

The conceptual consequences of this privilege given by the author to the cognitive dimension of the institutional phenomenon, as well as its monoparadigmatic focus concerning cognition and institutions, were generalized for all the principles of institutional theory, demarcating forthcoming criticism. Therefore, despite the explicit paradigmatic change in Zucker's proposal $(1987,1991)$ and its implications, among which the more relevant are the shifting of emphasis from normative aspects to cognitive aspects, from the structural approach to the process approach and the rescuing of the actor, both individual and organizational, as an essential agent in the process, institutionalization continues to be identified, in essence, with permanence, homogeneity and conformity. Normalization is still looked upon as a fundamental characteristic of the process, from the arguments of authors such as Selznick (1992, p. 232, emphasis in original) who states "as an abstract idea, shorn of normative connotations, institutionalization is the emergence of orderly, stable, socially integrating patterns out of unstable, loosely organized, or narrowly technical activities". It may be noted that at the more advanced stage of institutionalization, the level of variation in the adoption of a cultural pattern is described by Tolbert and Zucker (1996) as being low, even when dealing with social actors with heterogeneous characteristics.

We believe that the insistence on such a connotation is also derived from the frequent highlighting given to certain arguments of DiMaggio and Powell $(1983,1991)$ which, in their attempt to distinguish types of isomorphism and institutional theory landmarks, established the division between coercive, mimetic and normative isomorphism, as well as between what was designated as old and new institutionalism and ended up implementing models that are still in use today in an excessively segmented way (see MIZRUCHI; FEIN, 1999). When dealing with organizational dynamics, the authors associate old institutionalism with change and new institutionalism with permanence. The little that has been discussed so far already reveals indications to deny the dichotomy impressed on this didactic distinction of DiMaggio and Powell $(1983,1991)$ on the part of some scholars. Indeed, we affirm that this dichotomy cannot be accepted as, contrary to what is proclaimed, the persistence of social patterns is not absent from the assumptions of the old institutionalism, nor is the social actor ignored, in consequence, in the new institutionalism. Nevertheless, it seems to be subjacent to such an effort of distinction a given valuing tendency, which is not clearly outlined, but emerges from the set of points that the authors utilize to characterize the two supposed phases of institutional theory and which persevere in the current critique of neoinstitutional theory, which serves to support Brazilian criticism in particular. 
When it comes to the means of ignoring the social actor in neoinstitutional theory, Oliver (1991), for example, seeks to clarify this mistake by proposing a typology of different strategic responses of organizations to environmental pressures, built on a basis of conjugation of the institutional and resourced-based views. She justifies the need to elaborate such a theoretic conciliation by detecting growing criticism of the lack of attention to the self-interested behavior and the active agency of organizations in answer to the environment as seen in part of the studies founded on institutional theory. The author synthesizes those aspects of institutional theory that reflect such a situation, which she utilizes to formulate the hypotheses of her study. They are: "Institutional environment; Nonchoice behavior; Conforming to collective norms and beliefs; Invisible pressures; Isomorphism; Adherence to rules and norms; Organizational persistence; Habit and convention; Social worthiness; Conformity to external criteria; Interests institutionally defined; Compliance self-serving" (OLIVER, 1991, p. 147).

Actually, the synthesis employed by Oliver (1991) exposes the main points which, attributed to institutional theory, or more commonly new institutionalism, are a target for criticism: theoretic opposition between institutional patterns and agency capacity (non-choice as a focus of institutional theory); conformity as a behavioral tendency resulting from the institutionalization process; persistence (non-change) as a product of the institutionalization process.

In this light, Oliver (1991) suggests that organizations respond in a different way to the environment depending on the formulation of strategic actions which vary from conforming to resistant, according to contextual pressures as well as their internal capacity and motives which generate such pressures, who controls them, the type of pressures, how, by what means and where they are exercised. Therefore, conformity to environmental demands is not inevitable. Nevertheless, by not supplying more detailed information concerning the way such variation may turn out, we imply that she supposes the use of the two theoretic approaches on which her studies are based to be relevant as mechanisms for the revision of possible organizational responses. This is what she does, albeit without reviewing their presuppositions. The only point of revision of institutional theory that may be present in her work is the idea of institutional conditions, whose definition allows us to presume that legitimacy, when considered an objective and exogenous pattern may be intentionally sought for and therefore institutional patterns may be the target of acceptance or rejection by organizations.

Although it is not a mere overlapping of theories, the notion of institutional conditions does not seem to be sufficient to supply those limitations identified in the neoinstitutional theory. On the contrary, they can even be maintained. As observed by Tolbert and Zucker (1996), Oliver (1991) concludes in her investigation that, depending on the degree of institutionalization, there will be a greater or lesser margin to resistance and change. In these terms, institution is still considered synonymous with conformity, persistence and non-action. However, even under the weight of a partial reading and therefore, of consent, albeit implicit, the critical argument of Oliver (1991) and other authors such as DiMaggio (1988) and Aldrich and Fiol (1994), highlights already existing but underdeveloped elements in neoinstitutional theory concerning agency capacity and its necessary relationship with the institutional phenomenonon.

However, despite several attempts to oppose aspects of the distinction employed by DiMaggio and Powell (1991), in the Brazilian context neoinstitutional theory continues to be understood by some authors from a narrow and strictly dichotomic viewpoint, being seen, therefore, as a perspective that prioritizes stability, persistence or permanence and the supposition that institutions are only restrictive of organizational action.

Although it questions the opposition between old and new institutionalism, the recent paper of Misoczky (2003, p. 158), for example, states that new institutionalism "suggests that individual preferences and basic categories of thought, like self, social action, the State and citizenship, are molded by institutional forces, emphasizes the ways in which action is structured and order made possible through systems of shared rules which [...] limit the inclination and capacity of actors to optimize". There remains the association of the presuppositions of the neoinstitutional theory with the notion of structured action, seen as a renewed version of non-action. Therefore the idea of considering 
them as a cause of excessive environmental determinism in that they are seen as opposites to the logic of strategic action predominant in the first phase of institutionalism.

It is also highlighted in Brazilian critique that there is the emphasis on the dimension of power as a way of overcoming a tendency that in the view of these authors is presented as conservative and marks the neoinstitutional theory in the wake of the shifting of the initial analytical focus from old institutionalism in the political nature of the relationship of the organization with the environment by the imperative of legitimacy as 'determinant' in this relationship as identified by Selznick (1996). Power is then conceived as fundamentally linked to intentionality, while a necessary condition which is brought from logic of change and diversity in institutional theory. In the words of Carvalho, Goulart and Vieira (2004, p. 11-12),

The specific character and distinct competence, central categories in the analysis of Selznick [...], emphasize diversity and organizational change; as legitimacy and isomorphism, bases of the formulation of Meyer and Rowan [...] highlight the homogeneity and persistence of organizational forms. Here the political nature of old institutionalism is also revealed by means of the centrality of power in the institutionalization process and the neutrality of the same process in the new version [...]. Conformity substitutes change and reproduction takes the place of transformation. Homogeneity is imposed on heterogeneity, the global on the local, adaptation on diversity.

However, authors like Perrow (1986) state that the main contribution of neoinstitutional theory for organizational study is to point out the influence of the environment by inserting legitimacy and isomorphism as vital factors in the survival of organizations. Thus, such differences, instead of a mark, result only in the adoption of other ontological and epistemological foundations by the neoinstitutional theory, as observed by Scott (2001), which is characteristic of scientific progress. Furthermore, as argued by Hrebiniak and Joyce (1985), in the field of organizational studies, a great deal of research deals with the extremes of a continuum as if they were simply mutually exclusive categories. There lies the danger of dichotomizing, as Whittington (1988) warns, focusing on one extreme all the while running the risk of obscuring the understanding and application of another.

On this ground, we understand that the solution proposed by some Brazilian scholars to reverse the supposed conservatism [determinism] of the neoinstitutional theory, whatever it may be, the return to the emphasis on power, invariably founded on the sole perspective of intentionality, is close to a rationalist assumption, at least when it comes to its subjacent voluntarist orientation. The denial of the primordial role of legitimacy and interpretation is added to by the omission of the notion of reciprocity as another basis that reveals the connection between organization and environment, better translated by the concept of embeddedness, defined by Granovetter (1985) and adhered to by proponents of the neoinstitutional theory, such as Fligstein (1985), DiMaggio and Powell (1991) and others.

In this light, we must call to mind that the neoinstitutional theory is more appropriately situated in an intermediate position in the continuum between determinist and voluntarist orientations in organizational action. Such a position expresses the understanding that it is formulated according to reciprocity between internal and external demands, from choices guided by the intersubjective interpretation of social actors concerning predominant rationality in its own social context (MACHADO-DA-SILVA; FONSECA, 1993; MACHADO-DA-SILVA; FONSECA; FERNANDES, 2000; FONSECA; MACHADO-DA-SILVA, 2002). In this case, we are referring to bounded rationality as in the manner defined by Simon (1979).

What is observed can also be described as the old fear of over-socialized conception of the human being, which is connected to traditional functionalism, having as its counterpoint the under-socialized conception of human being typical of rationalism (GRANOVETTER, 1985). Yet, such categories do not represent what seems to be contained, even when couched in embryonic terms, in the neoinstitutional theory and in part of the academic production designed to be new institutionalist. Despite the monoparadigmatic positions given so far, among which that which prescribes power as an analytical element central to the relationship of the organization and the environment, neoinstitutional theory seems to be better understood when it is seen as an effort to overcome certain paradigmatic obstacles of social sciences. This is the idea that is developed further on in this paper, as well as the 
presentation of another source of explanation for the agency and its association with power, change and organizational heterogeneity in an inversion of the argument which is predominant among Brazilian critics.

\section{INSTITUTIONAL THEORY AS A MULTIPARADIGMATIC THEORY}

Under the influence of the schematic view proposed by Burrell and Morgan (1979), a great number of the supporters of the organizational theory seem to find difficulties in thinking beyond the paradigmatic frontiers that they rigidly set in place, with clearly didactic goals, as they rightly observe. Thus, even when faced with theoretic perspectives that are difficult to adapt to when it comes to their epistemological and ontological bases, some researchers tend to stick to certain conceptual aspects and ignore others and formulate classifications that are most convenient to their own intentions when perhaps recognizing the impossibility of adjusting to the conventional types ought to be a more coherent attitude. This would seem to be the case with the principles of the neoinstitutional theory.

DiMaggio and Powell (1991, p. 8) state that in organizational studies and in sociology, the neoinstitutional theory is characterized by four main elements: "a rejection of rational-actor models, an interest in institutions as independent variables, a turn toward cognitive and cultural explanations, and an interest in properties of supraindividual units of analysis that cannot be reduced to aggregations or direct consequences of individuals' attributes or motives". As has been observed, such elements delimit the criticism of neoinstitutional theory. Although the existence of these points cannot be denied as relevant in the domain of the new institutionalism, we intend to prove that they constitute a specific version of neoinstitutional theory in organizations, without exhausting all their possibilities.

Concerning the rejection of the models based on the assumption of rational actors, it has become conventional to consider the neoinstitutional theory as a deterministic approach and the processes of institutionalization as related to non-action. Indeed, Tolbert and Zucker (1966) oppose what they call the rational-actor model to the institutional model, proposing the overcoming of the institutional versus rational dichotomy. It can be seen that after observing this dichotomy, the authors identify a social actor model (therefore institutional), associated with individuals that are excessively socialized, who accept and follow social norms without questioning, reflecting or resisting according to their personal interests.

Such a consequence of the institutionalization processes reflects a misunderstanding interpretation of the work of Berger and Luckmann $(1967$, p. 55), which is at the very phenomenological foundation of several institutionalist studies, when they reveal that "institutions also, by the very fact of their existence, control human conduct by setting up predefined patterns of conduct, which channel it in one direction as against the many other directions that would theoretically be possible". Given this deterministic perspective of action, which is not found in the general conception of the social construction of reality of these authors, Tolbert and Zucker (1996), for example, criticize the idea in the article of Meyer and Rowan (1977) concerning the possibility of disconnection between formal institutionalized structures and the technical operation of organizations. In fact, they argue that from Berger and Luckmann's (1967) perspective higher degrees of institutionalization would not allow different organizational responses but the other way around. Among other aspects to be highlighted in this paper at the right moment, despite its partial validity, we maintain that this critique does not reflect the paradigmatic multiplicity that is found in the idea of Meyer and Rowan (1977). Nor does it reflect the relational logic found in the view of Berger and Luckmann (1967).

Beyond the phenomenological argument, Hasselbladh and Kallinikos (2000) highlight an approach that they define as symbolic functionalism. This definition implies the possibility of the occurrence of several levels or social spheres of production of institutionalized patterns and their strategic use in certain orders to obtain legitimacy even when in the immediate local context of the activity of the organization the degree of institutionalization of these patterns is low. Furthermore, it implies a 
different conception of institution, wider ranging than merely sharing meanings or social typifications. In the words of Selznick (1996, p. 273) it involves recognizing that "the formal structure is institutionalized from without as well as from within" of the organization and that these two flows, if seen as distinct moments rather than simultaneous, may not coincide, be it in their apparent or operational dimensions, be it in their meaning.

Therefore, the idea of Meyer and Rowan (1977) consists of an example that which has been increasingly designated as institutionalized or structured cognition patterns (SELZNICK, 1996; MACHADO-DA-SILVA; BARBOSA, 2002; COCHIA; MACHADO-DA-SILVA, 2004), and how this concept allows for the discussion of power from the cognitive and cultural perspective, focusing interests in contrast to what is presumed in investigations of a monoparadigmatic nature. As Selznick (1996) admits, this aspect of the neoinstitutional theory is not in keeping with the supposition that it sustains the suppression of rational capacity and that it is therefore determinist. According to his words, the "new theorists rightly give great weight to 'structured cognition'. This very useful idea reminds us that the interaction of culture and organization is mediated by socially constructed mind, that is, by patterns of perception and evaluation" (SELZNICK, 1996, p. 274). This argument is of a functionalist nature, condensed in that it is conceived as 'thick institutionalization' by observing that "formal systems act only through people. A social reality must be created, and that reality, which has its own dynamic and its own imperatives, lends texture to the organization" (SELZNICK, 1996, p. 235). From this point of view, functionalism is mixed with a constructivist and interpretive approach, which does not seem to have been noted by Tolbert and Zucker (1996), and also by the aforementioned Brazilian critics.

Therefore, what Selznick (1996) identifies in the new institutionalism is not denial of rationality of the agent and, therefore, the capacity of the agency, but the inclusion in organizational studies of the idea of bounded rationality as a principle of decision-making and interaction as is also stated by Roberts and Greenwood (1997), Machado-da-Silva, Fonseca and Fernandes (2000), Fonseca and Machado-da-Silva (2002), Crubellate, Grave and Mendes (2004), and others. In accordance with Beckert (1999), we understand that the neoinstitutional theory contributes to the substitution of the notion of culturally dominated actors, or rational actors who cannot follow their instrumental course of decision-making because of institutionalized practices in an organizational field.

There is a second version that appears not to reject, but becomes more receptive to those models by acceptance of the idea that the mind of the organizational agents is socially (culturally and cognitively) constructed (GRANOVETTER, 1985; SELZNICK, 1996). Therefore, their action, even though intentionally rational, remains limited by institutionalized patterns. This notion of limits of rationality in its original source or in its institutional application rests on a multiparadigmatic approach of social theory, since it lies in structural and interpretive assumptions, at the very least.

In the following section of this paper, we will discuss the complementary version of this notion of limitation of rationality, defending an institutional analysis perspective which, it seems plausible to support, states that even if institutional patterns limit the possibility of rational action, it is those same patterns that concomitantly enable for some action and, thus, for some rationality. The central argument to be developed is: with institutional references, we have rationally limited actions. In the absence of institutions, what we have is action that cannot be properly classified as social, therefore, a form of 'non-action' from the viewpoint of associated human life.

Another point which is raised in this discussion is the notion of institutions as independent variables, which is predominant in institutional theory. Since "actors and their interests are institutionally constructed" (DIMAGGIO; POWELL, 1991, p. 28), such a direction of determination remains to be explored. The facing of this supposed tendency in general occurs through the attempt to focalize the process of institutionalization, as done by Zucker (1991), Tolbert and Zucker (1996) and others. Nevertheless, the efforts to emphasize the process of institutionalization frequently do not contemplate a discussion of change, capacity of agency, power and interests like constitutive elements of the process itself. In most attempts, such elements continue to be defined as external and merely concomitant to the phenomenon of institutions and the process of institutionalization, generating a 
mechanist and static perspective of social change, as it operated within a monoparadigmatic reference framework.

Tolbert and Zucker (1996), for example, face the institutionalization process as unidirectional, following logic of habitualization, objectivation and sedimentation. From this angle, the apparent reconciliation between institutional structures and agency is realized, more through the joining and accommodation of theories than through reformulation and advancement of institutional theory. This is which allowed, in the words of Seo and Creed (2002), for the paradoxes of contraposition between institution and agency and for the possibility of institutional change without highlighting the active role and embeddedness of agency and interests. These authors elaborate their conception from the dialectic perspective of institutional theory, which was not apprehended or is not recognized by some Brazilian critics of the new institutionalism, who insist on the mechanist version of the insertion of the category of power as sufficient to reverse the view of institutions as independent variables. Other versions of this supposed reconciliation between institutions and change in general merely invert the logic of relationship and therefore institutions cease to be seen as independent variables, the cause of interests and actions, to become dependent variables, product of the intentions of powerful and conscious agents who are aware of their own interests or consider institutional contradictions to be the source of their changes. Such attempts reflect what DiMaggio and Powell (1991, p. 30) define as "extrainstitutional sources of institutional change".

However that may be, we believe that an advancement in the development of the presuppositions of neoinstitutional theory must account for change as part of the institutionalization process and not as a correlated and external phenomenon. It is necessary to reformulate the articulation between components of the theory, in a way that institutions and change cease to be seen as contradictory and that can be identified, that is similar to the proposals of Seo and Creed (2002), Dacin, Goodstein and Scott (2002) and other scholars, institutional sources of institutional change over time.

This possibility of dealing with change in the neoinstitutional theory, contrary to that which authors like DiMaggio and Powell (1991) seem to support and which is a central argument in the work of Carvalho, Goulart and Vieira (2004), has not happened despite their cognitive-cultural focus but above all because of it. The origin of this approach is found in the proposal of Ranson, Hinings and Greenwood (1980). In line with Giddens' (1978) structuration theory, they understand structure as mutually constituted by and constitutive of action, while product of a prescribed framework of rules and procedures and emerging patterns of interaction, resulting from their continuous interpretation in the routine of the organization. There the idea of reciprocity can be witnessed beyond the analytical limitation of the fourth point highlighted by DiMaggio and Powell (1991) as a characteristic of the neoinstitutional theory, i.e., the analysis of supraindividual structures.

Scott $(1994,1995)$ neither seems to view the neoinstitutional theory through a distinction of variables or supraindividual structures. By proposing a theoretic synthesis, he includes the notions of the social actor and interpretation as important elements in the institutionalization process. Such circularity can also be seen as reciprocity should the concept of social action upon which this approach is founded highlighted. In his words "following Weber [...] action is viewed as social only to the extent that actors attach meaning to it. Environmental stimuli must be cognitively processed by actors - interpreted by individuals employing socially constructed symbol systems - before they can respond by taking action" (SCOTT, 1995, p. xiii).

If Ranson, Hinings and Greenwood (1980) make use of the structuration theory, Scott $(1994,1995)$ implicitly adheres to neofunctionalist sociology. In this sense, such authors represent a version of the new institutionalism that is not restricted to the characteristics proposed by DiMaggio and Powell (1991), since they deal with the process of institutionalization in a multiparadigmatic and organic way, based on cognitive-interpretive logic. Ignoring this version is justified only by the partiality of the reader or by the political bias of the interpretation, even because that is what has prevailed in the main research centers of neoinstitutional theory ever since the mid-nineties of the twentieth century and not the supposed determinist source, as is observed by Seo and Creed (2002) and others. 
One of the main theoretical elements that allows for the adoption of this institutional approach is the agency notion which, discussed elsewhere, implies recognizing that the institutionalization process, while a complex phenomenon, does not discard, but presupposes, both change and persistence, both social embeddedness and autonomy, at both the micro-social (organizations and individual agents) and the macro-social levels.

\section{Structure, Agency and the PreCedence OF InTERpretation: Institutionalization AS A ReCURSIVE PROCESS}

The concept of agency subjacent to the mechanicist perspective of social change, and the manifest purpose of some authors to resurrect the political perspective for understanding the institutional phenomenon are now matters that receive most attention. To this end, it is essential to remember from the outset the words of Selznick (1992, p. 238, emphasis added) that "agency connotes competence, intentionality, and accountability. To be an agent is to act purposively". Of similar importance to this argument are the considerations of Colomy (1998), conceiving the neoinstitutional theory as a carrier of a concept for practical action, where the routine nature of human conduct stands out and helps characterize the actors themselves and their interests as constituted by the institutions. To him, by prioritizing reproduction in detriment of transformation, the neoinstitutional theory ends up reducing agency to conformity when in matters of change, in particular, should contemplate both the typifying and inventive, both reproductive and reconstructive dimensions of social action.

It seems that Colomy (1998) does not realize that the limitation of neoinstitutionalism that he himself identified, is repeated other way around in the rationalist view of institutional entrepreneurship, his perspective of analysis, as well as in the proposal for rescuing the concept of power in the manner previously discussed. In other words, if the presuppositions of the neoinstitutional theory do not account for the processes of reconstruction and institutional change (as some scholars have claimed), the voluntarist perspectives also do not satisfactorily explain the typifying and reproductive aspects of social life. This simple statement shows that such perspectives are equally incapable of including the implicit circularity of the concept of social action. It is this need to break with the dichotomy of reproduction versus reconstruction that constitutes the effort made by the followers of a sociological orientation based on the idea of practical action, among them Ranson, Hinings and Greenwood (1980), Giddens, (1984), Hinings and Greenwood (1988), Machado-da-Silva and Fonseca (1993, 1996a).

Despite the lucidity with which he identifies the current challenge of the neoinstitutional theory, Colomy (1998) makes a mistake concerning the meaning that he attributes to the concepts of enactment and agency. As for the first concept, his adequate discussion extrapolates the goal of this article. For the time being, it is enough to say that in order to notice the error of equating it to the mere reproduction of reality, it would be necessary to include in such a discussion the notion of representation also as an inventive configuration, especially in the multiparadigmatic perspective of authors such as Weick (1969, 1995, 2001), and Tsoukas and Knudsen (2002).

As for the second concept, Colomy (1998) states that the notion of agency that is predominant in the institutional theory is linked to the traditional functionalist paradigm, especially the Parsonian notion of structural change. He then seems not to recognize, in the same way as some of the authors that have been quoted, the multiparadigmatic nature of the institutional theory, neglecting to capture all the complexity contained within it or, at least, in what it is allowed to develop, especially in the field of organizational studies.

Giddens (1984) in like manner as Selznick (1992) also associate agency to intentionality. However, he admits that intention is a relevant aspect, although not enough to explain the capacity of agency. Thus, he considers that agency does not consist only of intention of individuals to do something, but in their ability to carry out their intentions in the first place, which means power: according to him, in the 
English dictionary, the word agent means "one who exerts power or produces an effect" (GIDDENS, 1984, p. 9).

In these terms, agency is the capacity to interfere in events, not necessarily intentionally. To act, no matter how intentionally, is to be meaningful, in that "action depends upon the capability of the individual to 'make a difference' to a pre-existing state of affairs or course of events" (GIDDENS, 1984, p. 14). With this definition in mind, the intentionality of the agent is not denied, nor is it faced as the main characteristic of the capacity of the agent. Even if all action bears initial intention, the result can never be explained completely by this intention, but only when the interference of unintended consequences is recognized. A determined action, when the individual intends result $\boldsymbol{A}$ and gets result $\boldsymbol{B}$, he is an agent for result $\boldsymbol{B}$, as he participated in carrying it out, albeit unintentionally. We can add to this the concept of bounded rationality, as mentioned in the previous section.

With this specific notion of agency, it becomes possible to visualize the interdependence between structures and social actions without succumbing to the idea of linear causality between them. It is in this way that Giddens (1984) understands structures as 'memory traces' that are manifested, reproduced and reconstructed in any practical human activity, in which the social actors are expressed as such. Therefore, beyond objective and external patterns constructed to put pressure on action, structures are references that remain virtual and latent until the moment in which a social practice occurs, making them both the medium and the outcome of them. In the words of Scott (2001, p. 50), "institutions impose restrictions by defining legal, moral, and cultural boundaries setting off legitimate from illegitimate activities [but] also support and empower activities and actors. Institutions provide guidelines and resources for acting as well as prohibitions and constraints on action". Therefore, recursiveness between structures and actions are based on the very process by which both emerge, with continuous configurations of interpretation.

However, although Giddens (1984) declares that institutions are made up of more long term practices, as lasting factors that bring solidity to social life across time and space, we cannot deduce from this statement the possibility of the occurrence of mere production or repetition and rigid permanence of patterns as characteristics in the process of institutionalization, because of the notion of practice, structure and agency that he set up. We believe that the principles of the structuration theory suggest that, instead of being understood as focuses of determination, institutions must be seen as condition for the manifestation of social structures and the capacity for agency, i.e., for reproduction and reconstruction of structures while individuals constitute and express themselves as social actors. This is the case if condition is understood as an occasion and opportunity, concomitantly in a positive and negative sense for potentiality and restriction.

In this light, three relevant matters stand out in the examination of the conventional criticism of the neoinstitutional theory. Firstly, agency and structure, "far from being opposed, in fact presuppose each other", as Sewell $(1992$, p. 4) very rightly observes, which remits to the notion of simultaneousness, reciprocity and embeddedness between the two phenomena in the moulds that have already been shown. Secondly, and as highlighted in the arguments of Giddens (1984), social structures and, as a result, rules, norms and patterns of cognition, actually must be considered as limiters and facilitators of action, never only as one or the other. This idea may be summarized by the adopted meaning of condition.

Finally, there is the process of institutionalization, if its recursive state is considered, as is our position here, it cannot be fully understood without the interpretation of the actions being witnessed as the aspect that allows for its development. The interpretation is the operational mechanism, of a cultural-cognitive nature, of the recursiveness inherent to institutionalization. It is what unleashes reciprocity between structure and agency, as action, in the Weberian tradition, presupposes the processing of external stimuli, i.e., the attribution of meaning. In this perspective, by setting any causal direction to the relationship between the structure and the action, a precipitated, not to say naïve, position is revealed. 
In the neoinstitutional theory, it is presumed that the process of recursiveness can be explained thus: any social actor, in any daily situation that involves resolving problems, for example, needs references to act. These references come in the form of guidance concerning the past, or habits, guidance for the present, or judgments and guidance for the future, or projections, according to the definition of Emirbayer and Mische (1998), and are delineated and consolidated by institutions such as the State, industry, professional associations, and others, according to DiMaggio and Powell (1983). Accessing such references is interpreting contemporary stimuli that supervene into the daily flow of practices set up by social structures.

What we must understand is that these references never come in a linear manner straight from the external source to the agent, but always through the meaning that he attributes to the context in which social practice emerges. It is worth clarifying that there is no denying that there is an objective side to these referential dimensions; what is denied is their direct influence on action. Delineated thus, the process of institutionalization becomes eminently dynamic instead of static; it includes agency, as well as social structures and takes place at the macro-social and micro-social levels. Consequently, it is the construction of meanings and interpretations that lends a dynamic character to institutionalization, not only intentionality, as the agent is concentrated only on the aspects that he perceives to be essential to solve the problem he is faced with (MACHADO-DA-SILVA; FONSECA; FERNANDES, 2000; FONSECA; MACHADO-DA-SILVA, 2002). It is also worth remembering that the institutionalization process implies a question of degree, in that the foundation and evolution of social structures vary according to historical, temporal and spatially delimited circumstances (POWELL, 1991; SCOTT, 1991; MACHADO-DA-SILVA; FONSECA, 1996b).

In synthesis, every institution is a condition for the social structure and for the agency. It both makes possible and limits the constitution and manifestation of the structure and the capacity of the agency. This does not only mean social structures, but also social practices which, in the words of Giddens (1984), possess greater spatial-temporal extension. The existence of institutions delimits and permits action. Nevertheless, their inexistence, if we can think of this possibility on an utopian plain, does not represent unrestricted freedom for social action, but social non-action because of the absence of references.

According to Weber ([1924] 1998), an institution is always a possibility for action. All action is based on a motive, from the agent's point of view, according to Cohn (1979); if this motive is always individual in the last instance, as stated by Weber ([1924] 1998); and if the institution concerns the action, it cannot imply only intentionality under the risk of getting into a conceptual contradiction. Therefore, institutionalization as a recurring process (institutionalizing), i.e., implying simultaneousness and reciprocity between structure and agency, conditions the action, in that it delimits it and makes it viable, making it increasingly more possible, and yet, without making it necessary or inevitable.

In this sense, there is not only the reproduction of structures, but the repetition of the opportunity for its reinterpretation over time; consequently, there can be reproduction and change. A rigid or fixed practice is not an institution. It is a 'dead structure' at a given moment, that is absent from the practical conscience of the social actors (GIDDENS, 1984). An institutionalized practice remains in a provisional and dynamic state of equilibrium: the higher the degree of institutionalization, the lesser the chances that it will be sharply changed. On the other hand, even a highly institutionalized practice is not unchangeable over time, as it will always be revealed in the context of social interactions, thereby being submitted to the possibility of maintenance or change in its structured aspects or in the actions resulting form, its structuring aspects.

It is important to point out that 'dead structures' differ from orders based on custom and habit. Weber ([1924] 1998, p. 215) defines custom as "typically regular behavior that is maintained within traditional limits solely by its habitual character and by "unreflected imitation"". According to the multiparadigmatic view of institutional theory, as we have defended here, it is a mistake to presuppose that it refers to complete homogeneity and permanence, at least when sufficient importance is given to the cultural-cognitive element inherent to all social relationships. 
In this direction, although it can still be admitted that institutions generally provoke the intention to acquiesce, this intention will necessarily be affected by the very fact that the interpretation implied in the process of forming actions, in the Weberian sense, will result in possible deviations from the original pattern. This is why even if equaled to custom or habit, institutions can only be thought of as regularities or possibilities and never as determinations, and this in result of the cultural-cognitive element implied in each and every human action rather than in spite of it.

\section{CONCLUSION}

The institutional theory has aroused a great deal of interest in the field of organizational studies, with increasingly more followers, especially since the late 1970s. If, on the one hand, this popularity might be seen as a product of its high explicative potential, on the other hand, it seems to have garnered intense critique that is not always guided by conceptual statements that are consistent enough to ensure adequate comprehension and the spread of its ideas. Within these criticisms, we find the supposed identification of the institutional perspective, so called new institutionalism, with permanence, homogeneity, conformity and determinism, especially when the focus falls on the investigation of organizational change or the process of institutionalization. Dancin, Goodstein and Scott (2002, p. 45) had already expressed similar concerns and observation when they stated that this critical focus "did little to tap the full power or potential of institutional theory". In agreement with these authors, we have sought to present in this paper elements that contribute to the adoption of an approach that might be capable of generating analyses and investigations that are more profitable to the progression of the neoinstitutional theory.

It is possible to deduce from what we have presented in the previous sections, that institutionalization is better analyzed in a multiparadigmatic view. From this point of view, structure and agency are connected recursively, based on interpretation, as a basic cognitive mechanism, which allows for reciprocity between these elements and, consequently, their simultaneousness in social practice and development and maintenance of the process over time. Thus, actors become the carriers of institutional meanings, as defined by Zilber (2002), by instilling actions into organizations through the interpretation of external and internal factors, to be legitimized by sharing and socialization. Structure and agency do not exist and are perpetuated by themselves, or through the mere direct influence of one on the other, but by the interaction between them, promoted by the interpretation of their components under conditions of legitimacy GIDDENS, 1984; SCOTT, 1995, 2001; WEBER, [1924] 1998; DANCIN; GOODSTEIN; SCOTT, 2002; ZILBER, 2002).

With these arguments, isomorphism or homogenization do not necessarily express non-change and non-action in the sense of absence of agency capacity or choice. To acquiesce to a social pattern presupposes interpretation and, as such, implies choice and action. Therefore, homogenization does not derive from unreflected reproduction but from regularity that originates from the acceptance of a certain action that, exactly because it is interpreted as legitimate, is reproduced by agents in social practice and is consolidated as an institutionalized pattern by being consented to as a desirable and viable choice. Reproduction generates regularity, not copy, because even if acquiescence is the intention, unintended consequences may lead to changes because of the diversity of sources of interpretation and logic of action, which give meaning to the context of the institution. There is no passiveness, quite the opposite. There is no permanence and conformity, but variation and change (RANSON; HININGS, GREENWOOD, 1980; GIDDENS, 1984; SCOTT, 1995; WEBER, [1924] 1998; MACHADO-DA-SILVA; FONSECA; FERNANDES, 2000; DANCIN; GOODSTEIN; SCOTT, 2002).

At this point, it is worth mentioning that legitimacy is guaranteed by internal attitude or an expectation of consequences, rather than by external imposition by agents, as described by Weber ([1924] 1998). Thus, interpretation is also firmly linked to legitimacy as a fundamental aspect for every institution, allowing us to understand why not just any regularity is considered an institution: as 
such, that regularity must be explained by the fact that individuals submitted to its validity accept that legitimacy.

When we admit that interpretation is crucial in the mediation between external factors and actions, it becomes unacceptable to suppose that the precedence of legitimacy in the neoinstitutional theory implies a reduction in the space for agency, interests, rationality, power and other elements that are representative of autonomy in any of the instances to which this concept can be applied, be it at the individual, organizational or societal level. What happens is the opposite of this. As shown by Giddens (1984), legitimation as a dimension of social systems keeps a constant connection with meaning and domination, which, are thus jointly involved in all action. In these terms, legitimacy is the key word in the neoinstitutional theory, as it is the element that allows for the maintenance or change of institutions: doubts as to the suitability of practices, norms and procedures because of internal and external pressures may not allow for reproduction of institutionalized patterns, causing the loss of their legitimacy; in other words, the unchaining of a process of deinstitutionalization, which demands the redefinition and subsequent relegitimation of new meanings and actions that are typical of the emergence of a process of reinstitutionalization (JEPPERSON, 1991; OLIVER, 1992; MACHADODA-SILVA; FONSECA, 1996a, 1996b).

Specifically, we claim that the simple mechanicist inclusion of power as a prevailing analysis element that is predominant in the process of institutionalization, does not allow the configuration of an approach that contemplates institutional change in all its aspects. Besides concentrating on structures and actions, it is necessary to identify the meaning attributed to them by social actors and the role they play in the process of unleashing change, as highlighted by Zilber (2002). It is necessary to consider, from the intentional point of view, that social actors who already have resources and, consequently, power, are not very enthusiastic about participating in changes that alter their status $q u o$. Thus, the isolated and rationalist exploration of power ends up dichotomizing the conception of society, with influential actors in the constant struggle for perpetuating the current situation on the one hand, and, on the other hand, peripheral actors who intentionally struggle to defend their actions.

In a recursive perspective that allows for the interconnection of power with other analysis categories, this dichotomic view is dissolved, both when the supposed dualism is broken between permanence and change. By linking power and legitimacy, it is recognized that those who possess resources and power have them because there is legitimacy. This in turn allows them to sustain their position and attract more resources or preserve what they already have. However, the validity of this is limited to the scope of intentionality on the part of the actors, and not to what may indeed happen, because a resource is valuable because it is socially interpreted as such, in the same way that the search for it and its ownership are legitimated in the social context.

When the interpretive aspect is taken into consideration, it is understood that, along with domination, legitimacy is power. It is further understood that it is necessary to identify some degree of social support, not always intentional, but always cognitive-normative, which accounts for the power of certain actors, which is converted, through the mechanism of reciprocity, into a resource to be employed by them for the maintenance or transformation of the current structural arrangement in the social system. Here, several groups seek to make their own interest predominant and, when one of them is successful, the norms, rules and meaning shared by the members are legitimate, guaranteeing them status and authority, which they seek to maintain (RANSON; HININGS; GREENWOOD, 1980). As they are structural attributes, they are only made effective when social actors interpret them and use them for guidance because of their values and interests, and the meaning they attribute to them. Even for coercion to be recognized as such, it is necessary to interpret it as coercion. For this reason, an institution is always a possibility; any analysis that is kept at the macro-social level of institutions will not allow them to be distinguished from 'dead structures'.

Another consequence of focusing only on the political nature of institutions in detriment of their cognitive-normative aspects, is to treat change as an inversion or revolution, i.e., as a punctual and radical event. Such a vision, as opposed to what has been said, is the permanence given to revolutions. In the version of the neoinstitutional approach that we have given here, it is admitted that some 
circumstances that generate an intense rupture of institutionalized patterns can cause radical changes at certain times by involving the loss of their legitimacy. Nevertheless, if we consider the development of institutions along a more long term we see that most changes tend to be constant and incremental and, at times, more deep than incremental, but even so, compatible with the logic of legitimacy in the social system, which cannot be considered monolithically; modern social systems are made up of different spheres of power and representation, understood as more or less inventive configurations that are more or less conformist or non-conformist. "Discontinuous, radical, or revolutionary change is, almost by definition, rare" (SCOTT et al, 2000, p. 346). This statement allows for, among other factors, the participation of the holders of the power to develop the process of change, even when they seek to maintain the status quo, and the transformation of organizations and peripheral actors in agents of change, even when all that is left to them is to acquiesce. It means that institutional limits are not surpassed by the suppression of institutions, otherwise mainly because of them.

The reflections traced in this paper lack unfolding of a methodological nature, susceptible to conducting theoretic-empirical investigations. Initially, we suggested that it is no longer fitting to restrict the analysis of the institutionalization process to the identification of the effect of the social structure on social behavior, or, contrarily, to the definition of intentional actions seeking to conform a certain institutional order favorable to the values and interests of rational actors. It is necessary to verify the current structural patterns, the actions that they allow for and limit, which meanings are constructed, modified and reproduced by the actors to respond to environmental circumstances, which implies strategies for research that can identify the interdependence between structure, interpretation and action, in different sociocultural contexts. To this end, the examination of interpretive schemes becomes essential to understanding the organizational dynamic as simultaneously involving change and stability, as revealed in the studies carried out by Bartunek (1984), Hinings and Greenwood (1988), Machado-da-Silva and Fonseca (1993, 1996a), Machado-da-Silva and Gonçalves (2000), and others.

On the other hand, explaining the changes in structure and social behavior also requires putting more stress on the analysis of the deinstitutionalization process. The importance of deepening the investigation resides in obtaining clarification on the motivating factors for breaking the legitimacy of practices and meanings, the intensity of the influence of environmental demands in the institution and the conditions that challenge the tendency for adapting to them. Although this has not been greatly explored in the specialized literature, Oliver (1992), for example, describes social, functional and political mechanisms located outside and within organizations as fundamental factors for the occurrence of processes of deinstitutionalization; Clark and Soulsby (1995) sought empirical evidence of their unchaining in the study of the transition from a centralized economy to a free market economy in the Czech Republic in the late 1980s; and Zilber (2002) revealed how feminist ideology that is predominant in a rape crisis center in Israel was altered by the dissemination of new meanings from the joined in the organization of therapeutically oriented members. The latter work is particularly interesting as it is based on the idea that institutionalization presupposes the examination of interplay between actions, meanings and actors, in a way that is similar to what we advocate in this paper.

Bearing in mind the complexity of the phenomena and the preceding relationships, it is also pertinent to employ for empirical research, designs that meet the requirements of the recurrent systemic-process approach, as we have proposed here. These designs should be configured preferentially in terms of use of multiple methods, with privilege for qualitative research procedures, with a longitudinal and historical perspective. This type of research seems to be the most appropriate for unraveling the articulation between structural references, domains of interpretation and action, even though complete understanding of the concomitance of manifestation, reciprocal adjustment, change and maintenance of them still persists as a methodological challenge to be overcome. Even so, we should not discard the use of quantitative procedures of research in combination with the qualitative procedures as long as the predominant logic is interpretive and not of linear causality. Photos of a social configuration, typical of a transversal cut, can be constituted in the initial phase of a longitudinal and historical research process to disclose the film that led to that configuration. 
Obviously, the recuperation of past events has limitations that need to be dealt with adequately when carrying out the research.

It is worth illustrating two possible focuses for investigation, among others that are equally recommendable. The first refers to the use of the methodology for social network analysis to verify the structure of the relationship between organizations (photo) in combination with the use of interpretive historical and longitudinal methods (film) of the reasons for this structural configuration; the concern must be that of trying to reveal and understand the structuring elements of this structured and also structuring situation. The second concerns the use of the methodology of in depth case study to examine the process of institutional diffusion within organizations, involving the actors, strategies and the mechanisms for attributing meanings to the various levels and segments of the organization, in the light of the different spheres of the environmental context.

In terms of ontological implications, an indispensable step for facing such an obstacle is to abandon the objectivist position, be it explicit or subjacent, to carrying out the greater part of organizational studies guided by the institutional analysis perspective, among which are included some that have been carried out by the authors of this paper. A quick example of the objectivist approach is that which reduced reality to the level of discourse as the resulting structure of solely purposive and conscious practices of domination and use of power. This eminently structural perspective, opposes the proposal made in this essay for a recurrent systemic-process approach for institutionalization, which imply that organizational discourse results from the duality of communicative actions and structural properties, recursively intermediated by the intersubjective interpretation of the actors involved, close in the way viewed by Heracleous and Hendry (2000).

On the other hand, it is important to stand out the possibilities of the proposed systemic-process institutional perspective of analysis for the study of strategic decisions in organizations, as they seem to constitute the context where recurrence between capacity of agency and structural forces are most evident. As a result, we may take an important step to overcoming the division between the field of organizational analysis and the field of strategy.

To round off this paper, we corroborate the idea of Bowring (2000) when he states that somewhere between the point of origin and the present, the notion of social construction of reality came to be applied in a linear causal logic, visible both in content and in form, even in the seminal works of Meyer and Rowan (1977) and DiMaggio and Powell (1983). The basic concept of intersubjectivity seems to have been resumed over time firstly to subjectivity and then to objective reality, depreciating the original concept of Berger and Luckmann (1967), recognized as one of the fundamental supports of the neoinstitutional theory. Perhaps this loss justifies the mistake in associating the new institutionalism with determinism and dualism, which has characterized the analysis of the organizational, institutional and environmental relationship as static and objectivist; therefore, disconnected from the human dimension, which allows it to be placed in an intermediate position that is neither voluntarist nor determinist, for understanding the social world and also as a relevant approach for the field of organizational studies.

\section{REFERENCES}

ADORNO, F. P. A tarefa do intelectual: o modelo socrático. In: GROS, F. (Org.). Foucault: a coragem da verdade. São Paulo: Parábola Editorial, 2004. p. 39-62.

ALDRICH, H.; FIOL, C. M. Fools rush in? The institutional context of industry creation. Academy of Management Review, v. 19, n. 4, p. 645-670, 1994.

BARTUNEK, J. M. Changing interpretive schemes and organizational restructuring: the example of a religious order. Administrative Science Quarterly, v. 29, n. 3, p. 355-372, 1984. 
BECKERT, J. Agency, entrepreneurs, and institutional change: the role of strategic choice and institutionalized practices in organizations. Organization Studies, v. 20, n. 5, p. 777-799, 1999.

BERGER, P. L.; LUCKMANN, T. The social construction of reality: a treatise in the sociology of knowledge. New York: Doubleday Anchor Book, 1967.

BOWRING, M. A. De/constructing theory: a look at the institutional theory that positivism built. Journal of Management Inquiry, v. 9, n, 3, p. 258-270, 2000.

BURRELL, G.; MORGAN, G. Sociological paradigms and organizational analysis. London: Heinemann, 1979.

CARVALHO, C. A.; GOULART, S.; VIEIRA, M. M. F. A inflexão conservadora na trajetória histórica da teoria institucional. In: ENCONTRO ANUAL DA ANPAD, 28., 2004, Curitiba. Anais... Rio de Janeiro: ANPAD, 2004. 1 CD-ROM.

CLARK, E.; SOULSBY, A. Transforming former state enterprises in the Czech Republic. Organizations Studies, v. 16, n. 2, p. 215-242, 1995.

COCHIA, C. B. R.; MACHADO-DA-SILVA, C. L. Ambiente, interpretação e estratégia em organizações paranaenses dos setores de vestuário e alimentos. Revista de Administração Contemporânea, Edição Especial, v. 8, p. 11-35, 2004.

COHN, G. Crítica e resignação: fundamentos da sociologia de Max Weber. São Paulo: T.A. Queiroz, 1979.

COLOMY, P. Neofunctionalim and neoinstitutionalism: human agency and interest in institutional change. Sociological Forum, v. 13, n. 2, p. 265-300, 1998.

CRUBELlATE, J. M.; GRAVE, P. S.; MENDES, A. A. A questão institucional e suas implicações para o pensamento estratégico. Revista de Administração Contemporânea, Edição Especial, v. 8, p. 37-60, 2004.

DACIN, T.; GOODSTEIN, J.; SCOTT, W. R. Institutional theory and institutional change: introduction to the special research forum. Academy of Management Journal, v. 45, n. 1, p. 45 $57,2002$.

DIMAGGIO, P. J. Interest and agency in institutional theory. In: ZUCKER, L. (Ed.). Institutional patterns and organizations: culture and environment. Cambridge: Ballinger, 1988. p. 3-21.

DIMAGGIO, P. J.; POWELL, W. W. The iron cage revisited: institutional isomorphism and collective rationality in organizational fields. American Sociological Review, v. 48, n. 2, p. 147-169, 1983.

. Introduction. In: POWELL, W. W.; DIMAGGIO, P. J. (Eds.). The new institutionalism in organizational analysis. Chicago: The University of Chicago Press, 1991. p. 1-38.

EMIRBAYER, M.; MISCHE, A. What is agency? American Journal of Sociology, v. 103, n. 4, p. 962-1023, 1998.

FLIGSTEIN, N. The spread of the multidivisional form among large firms, 1919-1979. American Sociological Review, v. 50, n. 3, p. 377-391, 1985.

FONSECA, V. S. da; MACHADO-DA-SILVA, C. L. Conversação entre abordagens da estratégia em organizações: escolha estratégica, cognição e instituição. Organizações \& Sociedade, v. 9, n. 25, p. 93-109, 2002. 
FOUCAULT, M. Microfísica do poder. Rio de Janeiro: Edições Graal, 1979.

GIDDENS, A. Novas regras do método sociológico. Rio de Janeiro: Zahar Editores, 1978. . The constitution of society. Berkeley: University of California Press, 1984.

GRANOVETTER, M. Economic action and social structure: the problem of embeddedness. American Journal of Sociology, v. 91, n. 3, p. 481-510, 1985.

HASSELBLADH, H.; KALLINIKOS, J. The project of rationalization: a critique and reappraisal of neo-institutionalism in organization studies. Organization Studies, v. 21, n. 4, p. 697-720, 2000.

HERACLEOUS, L.; HENDRY, J. Discourse and the study of organization: toward a structurational perspective. Human Relations, v. 53, n. 10, p. 1251-1286, 2000.

HININGS, C. R.; GREENWOOD, R. The dynamics of strategic change. New York: Basil Blackwell, 1988.

HREBINIAK, L. G.; JOYCE, W. F. Organizational adaptation: strategic choice and environmental determinism. Administrative Science Quarterly, v. 30, n. 3, p. 336-349, 1985.

JEPPERSON, R. L. Institutions, institutional effects, and institutionalism. In: POWELL, W. W.; DIMAGGIO, P. J. (Eds.). The new institutionalism in organizational analysis. Chicago: The University of Chicago Press, 1991. p. 143-163.

LACEY, H. Valores e atividade científica. São Paulo: Discurso Editorial, 1998.

MACHADO-DA-SILVA, C. L.; BARBOSA, S. de L. Estratégia, fatores de competitividade e contexto de referência das organizações: uma análise arquetípica. Revista de Administração Contemporânea, v. 6, n. 3, p. 7-32, 2002.

MACHADO-DA-SILVA, C. L.; FONSECA, V. S. da. Estruturação da estrutura organizacional: o caso de uma empresa familiar. Organizações \& Sociedade, v. 1, n. 1, p. 42-71, 1993.

. Patterns of meaning: institutionalization and circumstances. In: PALMER, G.; CLEGG, S. R. (Eds.). Constituting management: markets, meanings, and identities. Berlin: De Gruyter, 1996a, p. 139-153.

Competitividade organizacional: uma tentativa de reconstrução analítica. Organizações \& Sociedade, v. 4, n. 7, p. 97-114, 1996 b.

MACHADO-DA-SILVA, C. L.; FONSECA, V. S. da; FERNANDES, B. H. R. Cognição e institucionalização na dinâmica da mudança em organizações. In: RODRIGUES, S. B.; CUNHA, M. P. (Orgs.). Estudos organizacionais: novas perspectivas na administração de empresas: uma coletânea luso-brasileira. São Paulo: Iglu, 2000. p. 123-150.

MACHADO-DA-SILVA, C. L; GONÇALVES, S. A.; Mudança organizacional, esquemas interpretativos e contexto institucional: dois casos ilustrativos. Revista de Estudos Organizacionais, v. 1, n. 2, p. 11-26, 2000.

MEYER, J. W.; ROWAN, B. Institutionalized organizations: formal structure as myth and ceremony. American Journal of Sociology, v. 83, n. 2, p. 340-363, 1977.

MISOCZKY, M. C. Poder e institucionalismo: uma reflexão crítica sobre as possibilidades de interação paradigmática. In: VIEIRA, M. M. F.; CARVALHO, C. A. (Orgs.). Organizações, instituições e poder no Brasil. Rio de Janeiro: Editora da FGV, 2003. p. 141-175. 
MIZRUCHI, M. S.; FEIN, L. C. The social construction of organizational knowledge: a study of the uses of coercive, mimetic, and normative isomorphism. Administrative Science Quarterly, v. 44, n. 4, p. 653-683, 1999.

OLIVER, C. Strategic responses to institutional processes. Academy of Management Review, v. 16, n. 1, p. 145-179, 1991.

. The antecedents of deinstitucionalization. Organization Studies, v. 13, n. 4, p. 563-588, 1992.

PERROW, C. Complex organizations: a critical essay. New York: McGraw-Hill, 1986.

POWELL, W. W. Expanding the scope of institutional analysis. In: POWELL, W. W.; DIMAGGIO, P. J. (Eds.). The new institutionalism in organizational analysis. Chicago: The University of Chicago Press, 1991. p. 183-203.

RANSON, S.; HININGS, B.; GREENWOOD, R. The structuring of organizational structures. Administrative Science Quarterly, v. 25, n. 1, p. 1-17, 1980.

ROBERTS, P.; GREENWOOD, R. Integrating transaction cost and institutional theories: toward a constrained-efficiency framework for understanding organizational design adoption. Academy of Management Review, v. 22, n. 2, p. 346-373, 1997.

SCOTT, W. R. Unpacking institutional arguments. In: POWELL, W. W.; DIMAGGIO, P. J. (Eds.). The new institutionalism in organizational analysis. Chicago: The University of Chicago Press, 1991. p. 164-182.

. Institutions and organizations: toward a theoretical synthesis. In: SCOTT, W. R.; MEYER, J. W. Institutional environments and organizations: structural complexity and individualism. London: Sage Publications, 1994. p. 55-80.

Introduction: institutional theory and organizations. In: SCOTT, W. R.; CHRISTENSEN, S. (Eds.). The institutional construction of organizations. London: Sage Publications, 1995. p. xixxiii.

. Institutions and organizations. 2. ed. London: Sage Publications, 2001.

SCOTT, W. R. et al. Institutional change and healthcare organizations: from professional dominance to managed care. Chicago: The University of Chicago Press, 2000.

SELZNICK, P. The moral commonwealth: social theory and the promise of community. Berkeley: University of California Press, 1992.

. Institutionalism 'old' and 'new'. Administrative Science Quarterly, v. 41, n. 2, p. 270-277, 1996.

SEO, M.; CREED, W. D. Institutional contradictions, praxis and institutional change: a dialectical perspective. Academy of Management Review, v. 27, n. 2, p. 222-247, 2002.

SEWELL JR., W. H. A theory of structure: duality, agency, and transformation. American Journal of Sociology, v. 98, n. 1, p. 1-29, 1992.

SIMON, H. A. Comportamento administrativo. Rio de Janeiro: Editora da FGV, 1979.

TOLBERT, P.; ZUCKER, L. G. The institutionalization of institutional theory. In: CLEGG, S. R.; HARDY, C.; NORD, W. R. (Eds.). Handbook of organization studies. London: Sage Publications, 1996. p. 175-190. 
TSOUKAS, H.; KNUDSEN, C. The conduct of strategy research. In: PETTIGREW, A.; THOMAS, H.; WHITTINGTON, R. (Eds.). Handbook of strategy and management. London: Sage Publications, 2002. p. 411-435.

WEBER, M. Economia e sociedade. 3. ed. Brasília: Editora da UnB, 1998. 2.v.

WEICK, K. The psychology of organizing. Reading, MA: Addison-Wesley, 1969.

. Sensemaking in organizations. Thousand Oaks, CA: Sage Publications, 1995.

. Making sense of the organization. Malden, MA: Blackwell Publishing, 2001.

WHITTINGTON, R. Environmental structure and theories of strategic choice. Journal of Management Studies, v. 25, n. 6, p. 521-536, 1988.

ZILBER, T. B. Institutionalization as an interplay between actions, meanings, and actors: the case of a rape crisis center in Israel. Academy of Management Journal, v. 45, n. 1, p. 234-254, 2002.

ZUCKER, L. G. Institutional theories of organization. Annual Review of Sociology, v. 13, p. 443464, 1987.

. The role of institutionalization in cultural persistence. In: POWELL, W. W.; DIMAGGIO, P. J. (Eds.). The new institutionalism in organizational analysis. Chicago: The University of Chicago Press, 1991. p. 83-107. 